\title{
Diagnosis of hydatidiform mole and persistent trophoblastic disease: diagnostic accuracy of total human chorionic gonadotropin (hCG), free hCG $\alpha$ - and $\beta$-subunits, and their ratios
}

\author{
Nienke E van Trommel ${ }^{1,2}$, Fred C G J Sweep ${ }^{1}$, Charles P T Schijf ${ }^{2}$, Leon F A G Massuger ${ }^{2}$ and Chris M G Thomas ${ }^{1,2}$ \\ Departments of ${ }^{1}$ Chemical Endocrinology and ${ }^{2}$ Obstetrics and Gynecology, Radboud University Nijmegen Medical Centre, PO Box 9101,6500 HB \\ Nijmegen, The Netherlands \\ (Correspondence should be addressed to C M G Thomas at Department of Chemical Endocrinology; Email: C.Thomas@ace.umcn.nl)
}

\begin{abstract}
Objective: Human chorionic gonadotropin (hCG) is widely used in the management of hydatidiform mole and persistent trophoblastic disease (PTD). Predicting PTD after molar pregnancy might be beneficial since prophylactic chemotherapy reduces the incidence of PTD.

Design: A retrospective study based on blood specimens collected in the Dutch Registry for Hydatidiform Moles. A group of 165 patients with complete moles (of which 43 had PTD) and 39 patients with partial moles (of which 7 had PTD) were compared with 27 pregnant women with uneventful pregnancy.

Methods: Serum samples from patients with hydatidiform mole with or without PTD were assayed using specific (radio)immunoassays for free $\alpha$-subunit $(\mathrm{hCG} \alpha$ ), free $\beta$-subunit (hCG $\beta$ ) and 'total' hCG (hCG + hCG $\beta$ ). In addition, we calculated the ratios hCG $\alpha /$ hCG + hCG $\beta$, hCG $\beta /$ hCG + hCG $\beta$, and $\mathrm{hCG} \alpha / \mathrm{hCG} \beta$. Specificity and sensitivity were calculated and paired in receiver-operating characteristic (ROC) curve analysis, resulting in areas under the curves (AUCs).

Results: hCG $\beta$, hCG $\beta / \mathrm{hCG}+\mathrm{hCG} \beta$ and hCG $\alpha / \mathrm{hCG} \beta$ show AUCs ranging between 0.922 and 0.999 and, therefore, are excellent diagnostic tests to distinguish complete and partial moles from normal pregnancy. To distinguish partial from complete moles the analytes hCG $\beta$, hCG + hCG $\beta$ and the ratio hCG $\alpha /$ hCG $\beta$ have AUCs between 0.7 and 0.8. Although hCG $\alpha$, hCG $\beta$ and hCG + hCG $\beta$ concentrations are significantly elevated in patients who will develop PTD compared with patients with spontaneous regression after evacuation of their moles, in predicting PTD, these analytes and parameters have AUCs <0.7.

Conclusions: Distinction between hydatidiform mole and normal pregnancy is best shown by a single blood specimen with hCG $\beta$, but hCG $\beta / \mathrm{hCG}+\mathrm{hCG} \beta$ and hCG $\alpha / \mathrm{hCG} \beta$ are also excellent diagnostic parameters. To predict PTD, hCG $\alpha$, hCG $\beta$, hCG + hCG $\beta$ and $\mathrm{hCG} \alpha / \mathrm{hCG} \beta$ are moderately accurate tests, although they are not accurate enough to justify prophylactic chemotherapy treatment for prevention of PTD.
\end{abstract}

European Journal of Endocrinology 153 565-575

\section{Introduction}

Human chorionic gonadotropin (hCG) is a glycoprotein hormone produced by trophoblastic tissue and therefore is a key marker in pregnancy and gestational trophoblastic disease (GTD) (1). A variety of pathological types of trophoblast are included in GTD comprising villous malformations of the trophoblast: hydatidiform mole, subdivided into complete and partial hydatidiform moles, and non-villous malformations of which choriocarcinoma is the most frequent (2). Genetically, complete moles are diploid (46 XX or XY) which is the result of an 'empty' oocyte (after degeneration of the nucleus) being fertilized by one haploid sperm, followed by duplication of its chromosome, or fertilization of an empty egg by two spermatozoa (3). The syndrome of partial (incomplete) mole has an ascertainable fetus (alive or dead) and a triploid karyotype (69 XXX or XXY) after fertilization of a normal ovum by two spermatozoa (3). Incidence of hydatiform mole is highest in South-East Asia, Indonesia, India and Turkey with rates ranging from 2 to 12 per 1000 pregnancies. In North America and Europe, incidence is lower: 0.5 to 1 per 1000 pregnancies. Interestingly, significant reductions in the incidence of 
hydatidiform mole have recently been reported in Korea, Japan and Taiwan to levels comparable to those in North America and Europe (4). In persistent trophoblastic disease (PTD), trophoblastic activity remains after evacuation of the hydatidiform mole as shown by subsequent unaltered high or even rising hCG concentrations in blood. The reported frequency of PTD is 20\% in complete hydatidiform mole (5) and 0.5 to $9.9 \%$ in partial hydatidiform mole (6-9). In order to prevent complications from metastatic disease, PTD needs to be treated. Prophylactic chemotherapy (started immediately after evacuation of the mole) reduces the incidence of PTD to $4-12 \%$ ( 10 , 11). Because of the large proportion of patients who will show spontaneous remission of molar pregnancy after evacuation and because of the side effects of chemotherapy, clinicians are reluctant to use prophylactic chemotherapy. It would therefore be helpful to identify patients at risk for developing PTD. hCG is composed of two non-covalently bound $\alpha$ - and $\beta$-subunits. The $\alpha$-subunit of hCG comprises 92 amino acids and is identical to the $\alpha$-subunit of the pituitary glycoprotein hormones follicle-stimulating hormone (FSH), thyrotropin (TSH) and luteinizing hormone (LH). The $\beta$-subunit is composed of 145 amino acids, which distinguish hCG from these other glycoproteins. In addition to intact hCG, free hCG $\alpha$-subunit, free hCG $\beta$-subunit, and the hCG $\beta$-subunit core fragment are present in blood. Since most hCG radioimmunoassays detect both intact hCG and free hCG these tests are designated 'total hCG' or 'hCG + hCG $\beta$ ' assays. In normal pregnancy, concentrations of intact hCG, hCG + hCG $\beta$ and hCG $\beta$ in blood double approximately every 2 days to reach a peak at 8 to 10 weeks of gestation. From week 10 to 20, these concentrations decline to levels comparable to those in early first trimester and from 20 weeks on they remain constantly low (12). In contrast, hCG $\alpha$ concentrations in blood increase steadily until the end of pregnancy (13). The production of subunits of hCG is under stringent physiological control in normal pregnancy, and is reported to be different in pathological states such as hydatidiform mole (1416), although the literature data are not unequivocal. In particular, the concentration of hCG $\beta$ and the ratio of hCG $\beta$ to total hCG $\beta$ is reported to be increased in molar as compared with normal pregnancy (17). Some studies, using a limited number of patients, reported that an increased ratio of hCG $\beta$ to total hCG $\beta$ identifies patients with molar pregnancy who are at risk of developing persistent disease (18-20), although other investigators did not report such an association (14).

The present retrospective study includes measurement of hCG $\alpha$, hCG $\beta$ and hCG + hCG $\beta$ and calculates the ratios of $\mathrm{hCG} \alpha / \mathrm{hCG}+\mathrm{hCG} \beta$, hCG $\beta / \mathrm{hCG}+\mathrm{hCG} \beta$ and $\mathrm{hCG} \alpha / \mathrm{hCG} \beta$ in blood taken before evacuation from 203 patients with hydatidiform mole of which 43 developed PTD. The aim of this study is to evaluate the clinical utility of the six hCG parameters by receiver-operating characteristic (ROC) curve analysis to distinguish normal pregnancy from hydatidiform mole, partial from complete mole, and to predict the occurrence of PTD.

\section{Materials and methods}

\section{Patients}

In The Netherlands, patients with hydatidiform mole can be registered, after informed consent, at the Dutch Central Registry for Hydatidiform Moles residing at the Radboud University Nijmegen Medical Centre (RUNMC). We have included 1630 patients in this database. We excluded all patients with a histological diagnosis of choriocarcinoma. In 692 registered patients with hydatidiform mole, hCG in blood was analyzed in our department at the RUNMC. After collection, blood samples were centrifuged and serum was sent to our institute and kept at $-20{ }^{\circ} \mathrm{C}$ until assayed. Of these 692 patients, 430 had to be excluded since no blood specimen was taken prior to evacuation. Another 58 patients were excluded to match the gestational age in the control group. This led to the selection of 204 patients (mean age 27.9 years, range 16 to 54 years). Of those 204 patients, 129 had a complete hydatidiform mole with normal serum hCG regression (Group 1), as derived from a normal regression curve constructed by Yedema et al. (21). Another 36 patients with a complete mole developed PTD after evacuation (Group 2) while 32 patients had a partial mole with normal hCG regression (Group 3) whereas 7 patients with a partial hydatidiform mole developed PTD after evacuation (Group 4). The pathology institution of the Dutch Central Registry reviewed the histology of all patients with a hydatidiform mole. The control group comprised 27 women (mean age 28.2 years, range 23 to 39 years) with uneventful pregnancies, whose blood was collected on a weekly basis between 7 and 16 weeks of gestation except in weeks 13 and 15 .

\section{Immunoassays}

All the measurements of 'total' hCG (i.e. intact hCG and free $\beta$-subunit, hCG + hCG $\beta$ ) or its free $\alpha$ - or $\beta$-subunit in serum were performed with sensitive and specific radioimmunoassays (RIAs) that have been developed in our laboratory. The RIAs of hCG + hCG $\beta$ and hCG $\beta$ have been described previously (22), while the hCG $\alpha$ RIA was developed recently. Polyclonal anti-rabbit antisera were used in the RIAs of hCG + hCG $\beta$ and hCG $\alpha$, and a monoclonal antibody (23) in the RIA for hCG 3 . A highly purified hCG $\beta$-subunit preparation labeled with iodine-125 $\left(\mathrm{NaI}^{125}\right.$, Amersham plc, Amersham, Bucks, UK) was employed as a tracer in the RIAs of hCG + hCG $\beta$ and hCG $\beta$, while the RIA of hCG $\alpha$ used $\mathrm{I}^{125}$-labeled hCG $\alpha$ subunit as a tracer. The RIAs were calibrated with the third International Standard (IS) Preparations for intact hCG, hCG $\alpha$-subunit or hCG $\beta$-subunit (WHO third IS hCG 75/537, hCG $\alpha$ 75/569 or hCG $\beta$ 75/551 respectively, 
all obtained from the National Institute for Biological Standards, Potters Bar, Herts, UK). Conversion factors are as follows: $\mathrm{hCG} \alpha$ : $1 \mu \mathrm{g} / \mathrm{l}$ is $0.0714 \mathrm{nmol} / \mathrm{l}$ and equivalent to $1 \mathrm{IU} / \mathrm{l}$; hCGß: $1 \mu \mathrm{g} / \mathrm{l}$ is $0.0426 \mathrm{nmol} / \mathrm{l}$ and equivalent to $1 \mathrm{IU} / \mathrm{l}$; hCG: $1 \mu \mathrm{g} / \mathrm{l}$ is $0.0267 \mathrm{nmol} / \mathrm{l}$ and equivalent to $9.29 \mathrm{IU} / \mathrm{l}$. The measuring ranges of the assays were $0.027-2.14 \mathrm{nmol} / \mathrm{l}(1-80 \mu \mathrm{g} / \mathrm{l}$ equivalent to $9.29-$ $743 \mathrm{IU} / \mathrm{l})$ for hCG + hCG $\beta, 0.0036-0.43 \mathrm{nmol} / \mathrm{l}(0.05-$ 6.0 IU/l or $\mu \mathrm{g} / \mathrm{l})$ for $\mathrm{hCG} \alpha$, and $0.0033-0.107 \mathrm{nmol} / \mathrm{l}$ $(0.078-2.50 \mathrm{IU} / \mathrm{l}$ or $\mu \mathrm{g} / \mathrm{l})$ for hCG . All the RIAs applied the same assay protocol. In brief, the procedure comprised the following steps. To increase the sensitivity of the RIAs, the mixtures of standard material or serum specimen together with the antiserum were incubated for $18 \mathrm{~h}$ at $20^{\circ} \mathrm{C}$, and after addition of labeled analyte this was followed by a second incubation $\left(6 \mathrm{~h}\right.$ at $\left.20^{\circ} \mathrm{C}\right)$. Antibody-bound and free analyte were separated by applying second antibody donkey anti-rabbit IgG coupled to cellulose (Sac-Cel, The Wellcome Foundation Ltd, Dartford, Kent, UK) in the case of the hCG + hCG $\beta$ and $\mathrm{hCG} \alpha$ RIAs, and by donkey anti-mouse IgG coupled to cellulose in the free hCG $\beta$ RIA. The RIA developed for $\mathrm{hCG} \alpha$ cross-reacted $100 \%$ (on a molar basis at $50 \%$ displacement) with the $\alpha$-subunits of LH, FSH and TSH, and $2 \%$, $3.6 \%, 13 \%$ and $17 \%$ with the WHO International Reference Preparations (IRP) of native hCG, TSH, LH and FSH respectively.

Intact hCG and the free hCG $\beta$-subunit are abundantly present in serum samples from normal or mole pregnancies (unlike LH and FSH which are both suppressed during pregnancy while TSH concentrations are very low). For this reason, it was necessary to conduct an affinity chromatography procedure to eliminate intact hCG and free hCG $\beta$-subunit from each serum sample prior to determining its free hCG $\alpha$-subunit concentration by this RIA. Thus, $100 \mu \mathrm{l}$ serum were transferred to a HiTrap N-hydroxy-succinimide (NHS)activated column (Pharmacia, Uppsala, Sweden) coupled to a polyclonal antiserum against free hCG $\beta$ subunit raised in rabbit, and the column effluent was checked by RIA for absence of the intact hCG and free hCG $\beta$-subunit present in the serum sample prior to chromatography. Next, the free hCG $\alpha$-subunit concentrations were determined with the hCG $\alpha$ RIA. The free hCG $\beta$-subunit RIA showed a cross-reactivity with intact hCG of $0.35 \%$ (on a mass basis, equivalent to $0.55 \%$ on a molar basis) as tested with the WHO third IS $75 / 537$ of hCG, $1.1 \%$ on a molar basis with nicked hCG (hCGn, WHO 99/642 Reference Reagent) and $0.4 \%$ with hCGßn (WHO 99/692 Reference Reagent) while the hCG + hCG $\beta$ RIA cross-reacted $100 \%$ on a molar basis with intact hCG and 1000\% with hCG $\beta$-subunit, and 228\% with hCGn and $507 \%$ with hCG $\beta n$ (which is of minor practical importance because these nicked forms of hCG mainly occur in urine). The 95th percentile of the reference interval of healthy non-pregnant controls for the hCG + hCG $\beta$ assay was established at $0.053 \mathrm{nmol} / \mathrm{l}(2 \mu \mathrm{g} / \mathrm{l}$ or
$18.6 \mathrm{IU} / \mathrm{l}$ of the WHO third IS hCG 75/537) (22), $0.286 \mathrm{nmol} / \mathrm{l}(4.0 \mu \mathrm{g} / \mathrm{l}$ or IU/l of the WHO third IS hCG $\alpha$ 75/569) with the $\mathrm{hCG} \alpha$ RIA, and $0.0085 \mathrm{nmol} / \mathrm{l}(0.20 \mu \mathrm{g} / \mathrm{l}$ or IU/l of the WHO third IS hCG $\beta$ 75/551) with the hCG $\beta$ RIA (24). The intraand interassay coefficients of variation $\left(\mathrm{CV}_{\mathrm{w}}, \mathrm{CV}_{\mathrm{b}}\right)$ for means of duplicate measurements for two serum pools (mean: $0.267 \mathrm{nmol} / \mathrm{l}(10 \mu \mathrm{g} / \mathrm{l}$ or $93 \mathrm{IU} / \mathrm{l})$ and $1.50 \mathrm{nmol} / \mathrm{l}(56 \mu \mathrm{g} / \mathrm{l}$ or $520 \mathrm{IU} / \mathrm{l})$ were $7.3 \%$ and $12 \%$ for the $\mathrm{hCG}+\mathrm{hCG} \beta$ RIA, $3.3 \%-5.6 \%\left(\mathrm{CV}_{\mathrm{w}}\right)$ and $7.2 \%-8.4 \% \quad\left(\mathrm{CV}_{\mathrm{b}}\right)$ with two serum pools (mean: $0.510 \mathrm{nmol} / \mathrm{l}(7.1 \mu \mathrm{g} / \mathrm{l}$ or $\mathrm{IU} / \mathrm{l})$ and $3.07 \mathrm{nmol} / \mathrm{l}$ $(43 \mu \mathrm{g} / \mathrm{l}$ or $\mathrm{IU} / \mathrm{l}))$ in the case of the $\mathrm{hCG} \alpha \mathrm{RIA}$, and 5.2\%-5.8\% $\left(\mathrm{CV}_{\mathrm{W}}\right)$ and $9.5 \%-9.9 \%\left(\mathrm{CV}_{\mathrm{b}}\right)$ with two serum pools (mean: $0.014 \mathrm{nmol} / \mathrm{l}(0.33 \mu \mathrm{g} / \mathrm{l}$ or $\mathrm{IU} / \mathrm{l})$ and $0.041 \mathrm{nmol} / \mathrm{l}(0.96 \mu \mathrm{g} / \mathrm{l}$ or $\mathrm{IU} / \mathrm{l}))$ in the hCGß RIA.

\section{Statistics}

Calculation of reference values for normal pregnancy To construct reference values for normal pregnancy, we collected blood samples in our control group on a weekly basis from week 7 to 16 of gestational age except in weeks 13 and 15 . We determined the longitudinal patterns ('response curve') of each experimentally determined hCG analyte (hCG + hCG $\beta$, hCG $\alpha$ and hCG $\beta$, all expressed in nmol/l), as well as for the calculated molar ratios of hCG $\alpha$ - and $\beta$-subunits to hCG + hCG $\beta$ (hCG $\alpha / \mathrm{hCG}+\mathrm{hCG} \beta$ and hCG $\beta / \mathrm{hCG}+\mathrm{hCG} \beta)$ and the ratio of hCG $\alpha$ to hCG $\beta$ (hCG $\alpha / \mathrm{hCG} \beta)$. In order to obtain normal Gaussian distributed data for the control group consisting of 27 pregnant women, we performed $\log$ transformations of all the determined $\mathrm{hCG} \alpha$ concentrations (nmol/l) and calculated the molar ratio of hCG $\alpha /$ hCG $\beta$, while we performed square root transformation of the serum concentrations of hCG $\beta$ $(\mathrm{nmol} / \mathrm{l}), \quad \mathrm{hCG}+\mathrm{hCG} \beta(\mathrm{nmol} / \mathrm{l})$ and its calculated molar ratio. Next, by subsequent pooling (over the weeks) of variances (25), we calculated P5, P50, and P95 for these transformed data (i.e. mean(log or square root) \pm 1.645 s.e.(log or square root)) to become, after back transformation, the reference values (the 5th, 50th, and 95th percentiles, P5, P50, P95) separately for each week of the gestational period for the three analytes and the three molar ratios.

Statistical comparison of pregnancy controls with molar pregnancy subsets Each individual log- or square root-transformed hCG serum analyte or parameter from the 27 control pregnancies was expressed as a multiple of the median (MoM) for each gestational week. Because the longitudinal patterns for each individual patient revealed rather constant MoMs along the gestational period studied, we could calculate the mean MoM (mMoM) for each patient over the entire pregnancy period studied - weeks 7 to 16 . From these mMoMs for each patient we calculated 
the 'grand' mMoM \pm S.E. Next, we calculated the MoMs for each of the available individual log- or square root-transformed hCG serum analytes of all the molar pregnancies. This was done for each mole by dividing the measured log- or square root-transformed blood concentration (or calculated ratios) of analyte or molar ratio by the corresponding P50 value of the control pregnancies as calculated and matched for the corresponding gestational week. Statistical significance of differences was tested with the Mann-Whitney U-test between the mean MoMs of all control pregnancies (the 'grand' $\mathrm{mMoM}$ ) versus the calculated mean MoM of all molar pregnancies or versus the various subsets of moles (complete moles, partial moles), as well as between complete versus partial moles, or the presence or absence of PTD in the case of molar pregnancies. The calculated MoM values of all six hCG analytes and parameters of control and study groups were utilized to construct ROC curves and to calculate areas under the curve (AUC) for assessment of diagnostic accuracy of the test. All calculations were conducted with SPSS (version 12.0) for Microsoft Windows XP (SPSS, Chicago, IL, USA). ROC curves represent the full spectrum of possible sensitivity-specificity pairs for a test in a clinical application (26). Usually, it is assumed that the study group has higher values of the tested parameters than the control group, resulting in an AUC between 0.5 and 1.0. Conversely, if results are lower in the study group than in the control group, an AUC between 0.0 and 0.5 is found (27) but this can easily be circumvented by reversing the state variable of the control and study group.

\section{Results}

\section{Serum hCG parameters in hydatidiform molar pregnancy}

Median serum hCG $\alpha$ concentrations increased steadily in the control pregnancies from $1.79 \mathrm{nmol} / \mathrm{l}(25 \mathrm{IU} / \mathrm{l})$ at 7 weeks of gestation to $11.4 \mathrm{nmol} / \mathrm{l}(160 \mathrm{IU} / \mathrm{l})$ at 16 weeks of gestation. Serum hCG $\beta$ and hCG + hCG $\beta$ concentrations were $0.248 \mathrm{nmol} / \mathrm{l} \quad(5.8 \mathrm{IU} / \mathrm{l})$ and $37.6 \mathrm{nmol} / \mathrm{l}$ (13 100 IU/l) respectively at week 7, showed a peak at $8-9$ weeks of gestation $(0.417 \mathrm{nmol} / \mathrm{l}$ $(9.8 \mathrm{IU} / \mathrm{l})$ and $59.6 \mathrm{nmol} / \mathrm{l}$ (21 000 IU/l) respectively) and then subsequently decreased to $0.032 \mathrm{nmol} / \mathrm{l}$ $(0.75 \mathrm{IU} / \mathrm{l})$ and $18.7 \mathrm{nmol} / \mathrm{l}(6500 \mathrm{IU} / \mathrm{l})$ respectively at week 16 of gestation. Fig. 1 shows the serum concentrations of hCG $\alpha$, hCG $\beta$, hCG + hCG $\beta$ and its calculated ratios (hCG $\alpha / \mathrm{hCG}+\mathrm{hCG} \beta$, hCG $\beta / \mathrm{hCG}+\mathrm{hCG} \beta$ and hCG $\alpha /$ hCG $\beta$ ) in complete and partial moles with or without PTD compared with the values in normal pregnancy between weeks 7 and 16 of gestation. In many molar pregnancies, hCG $\alpha$ concentrations in serum (Fig. 1A) are below the P50 levels of normal pregnancy. The $\mathrm{hCG} \alpha / \mathrm{hCG}+\mathrm{hCG} \beta$ ratio in the majority of molar pregnancies is below P5 (Fig. 1D) while almost all $\mathrm{hCG} \alpha / \mathrm{hCG} \beta$ ratios are below P5 of normal pregnancy (Fig. 1F). In contrast to this, hCG $\beta$ and hCG + hCG $\beta$ concentrations, and the ratio hCG $\beta / \mathrm{hCG}+\mathrm{hCG} \beta$ are mostly above the corresponding $\mathrm{P} 95$ levels of normal pregnancy (Fig. 1B, C and E).

\section{Comparison of serum hCG analytes and parameters in hydatidiform molar vs normal pregnancy}

For each of the six hCG analytes and parameters investigated, we calculated the mean MoM (mMoM) values and their standard errors (s.e.) for the total and the individual groups of complete and partial molar pregnancy as compared with normal pregnancy (Table 1). This table also shows the comparisons between complete and partial moles, as well as all moles (complete and partial) without vs all moles with PTD.

The mean MoMs calculated for the concentrations of $\mathrm{hCG} \beta$, hCG + hCG $\beta$ and the ratio hCG $\beta / \mathrm{hCG}+\mathrm{hCG} \beta$ were significantly higher in all molar pregnancies as well as in the complete molar pregnancy group compared with values in normal pregnancies (Table $1 \mathrm{~A}$ and B). Comparable differences were also observed in the case of partial molar vs normal pregnancy except for hCG + hCG $\beta$ value, which was not significantly different (Table 1C). The mMoMs for the ratios of $\mathrm{hCG} \alpha / \mathrm{hCG}+\mathrm{hCG} \beta$ and $\mathrm{hCG} \alpha / \mathrm{hCG} \beta$ in the all moles group and in its two subset groups were significantly lower than in normal pregnancy (Table 1AC). The increase of the mMoMs observed for the group of all molar pregnancies (Table 1A), as well as for the subsets of complete (Table 1B) or partial (Table 1C) moles was highest in the case of hCG $\beta$, followed by the ratio of hCG $\beta / \mathrm{hCG}+$ hCG $\beta$ (Table $1 \mathrm{~A}-$ C). The decrease of the mMoMs was highest in the case of the ratio of $\mathrm{hCG} \alpha / \mathrm{hCG}+\mathrm{hCG} \beta$ (Table $1 \mathrm{~A}-\mathrm{C}$ ).

\section{Comparison of serum hCG parameters in groups of hydatidiform molar pregnancy}

The comparison between the complete and the partial molar pregnancies (Table 1D) showed that the mMoMs of both hCG $\alpha$ and the ratio of hCG $\beta / \mathrm{hCG}+$ hCG $\beta$ were not different, whereas the mMoMs for hCG $\beta$ and hCG + hCG $\beta$ in the partial moles were significantly lower than in the complete molar pregnancies $(P<0.001)$. In contrast to this, the mMoM of the ratios of $\mathrm{hCG} \alpha / \mathrm{hCG}+\mathrm{hCG} \beta$ and $\mathrm{hCG} \alpha / \mathrm{hCG} \beta$ in partial moles were significantly higher than those of complete molar pregnancy (Table 1D). In the case of all molar pregnancies with PTD as compared with all molar pregnancies without PTD, the three calculated ratios (hCG $\alpha / \mathrm{hCG}+\mathrm{hCG} \beta$, hCG $\beta / \mathrm{hCG}+\mathrm{hCG} \beta$ and $\mathrm{hCG} \alpha / \mathrm{hCG} \beta$ ) were not significantly different, whereas the mMoM of all measured hCG analytes (hCG $\alpha$, hCG $\beta$ and hCG + hCG $\beta$ ) were significantly higher in 
A

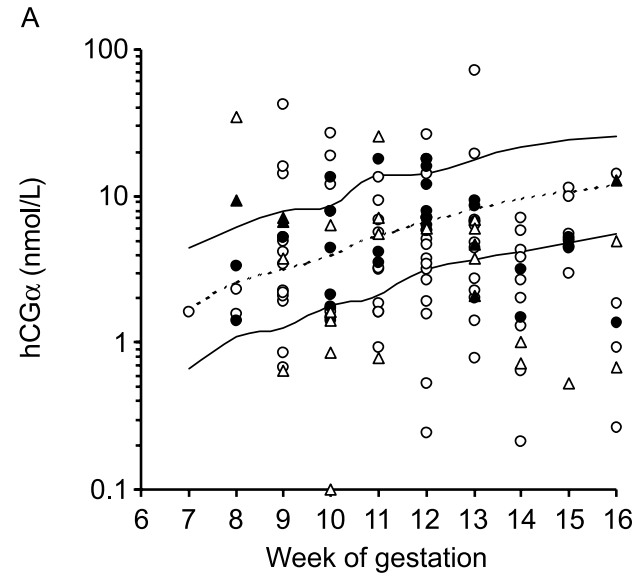

C

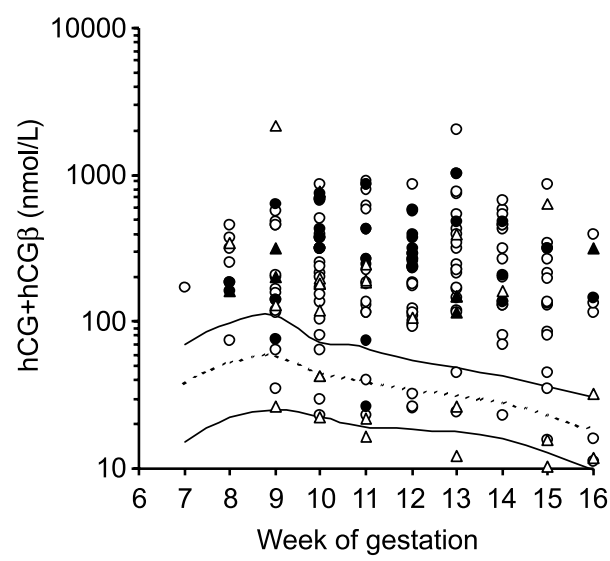

E

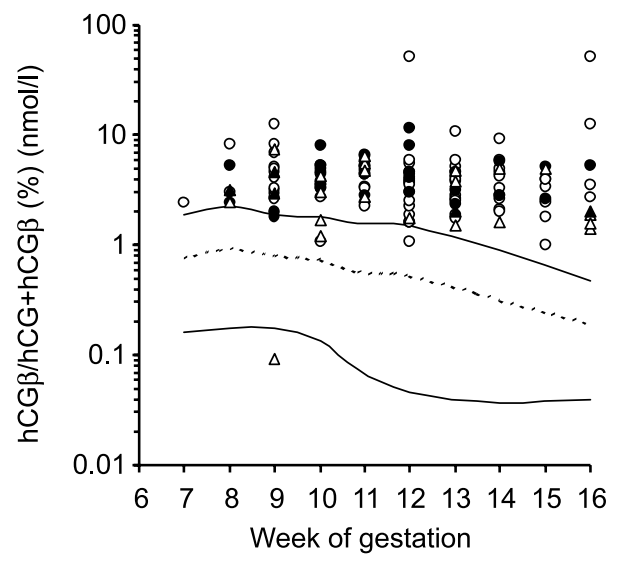

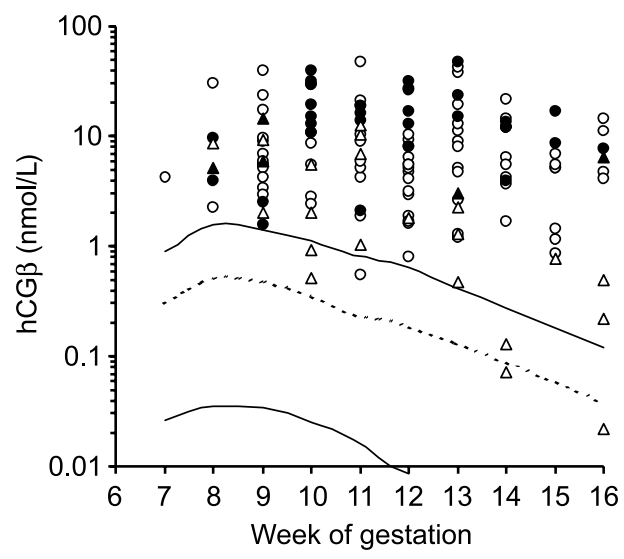

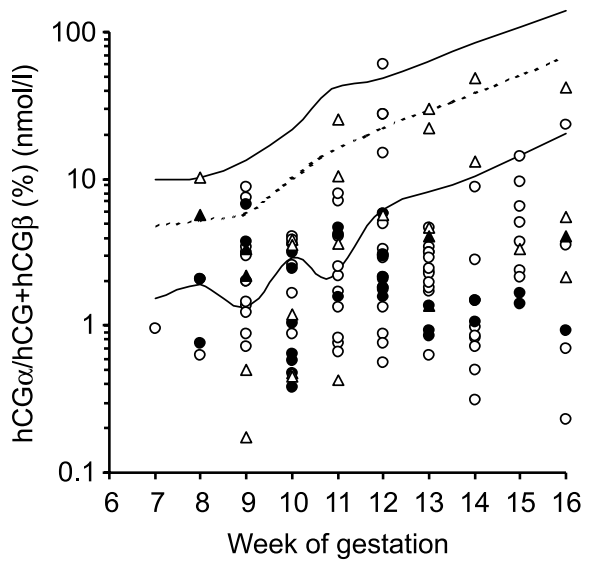

$\mathrm{F}$

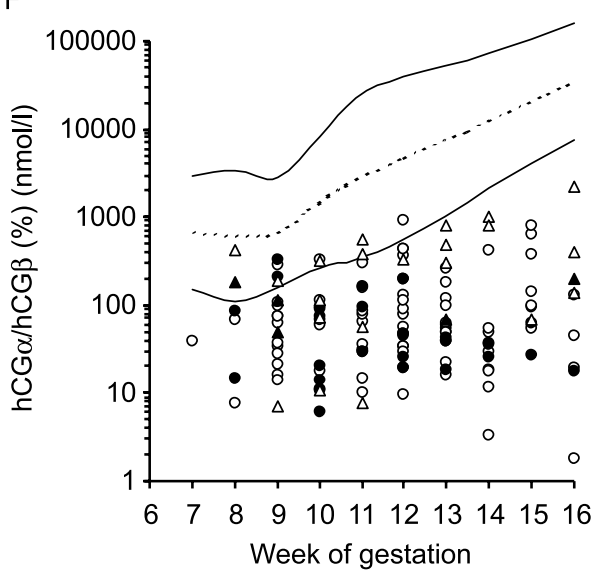

Figure $1 \mathrm{hCG} \alpha, \mathrm{hCG} \beta, \mathrm{hCG}+\mathrm{hCG} \beta, \mathrm{hCG} \alpha / \mathrm{hCG}+\mathrm{hCG} \beta, \mathrm{hCG} \beta / \mathrm{hCG}+\mathrm{hCG} \beta$ and $\mathrm{hCG} \alpha / \mathrm{hCG} \beta$ in partial or complete mole with or without persistent trophoblastic disease compared with normal pregnancy $(n=27)$. The two solid lines represent the 5th and the 95th percentile, whereas the dotted line represents the 50th percentile of normal pregnancy. Group 1(O), complete mole without PTD

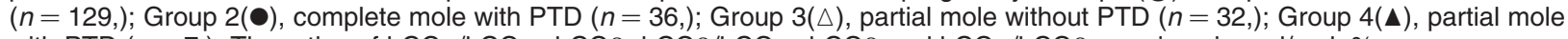
with PTD $(n=7$,$) . The ratios of h C G \alpha / h C G+h C G \beta, h C G \beta / h C G+h C G \beta$ and $h C G \alpha / h C G \beta$ are given in $\mathrm{mol} / \mathrm{mol}, \%$.

those cases where women developed PTD as compared with those who did not (Table 1E).

\section{Diagnostic accuracy}

We established diagnostic accuracy by calculating specificity and sensitivity for the comparisons already presented in Table 1. Based on these data we constructed the corresponding ROC curves for each of the three hCG analytes determined in blood specimens collected prior to evacuation as well as for the three ratios derived from these measurements (Fig. 2). We then calculated the corresponding AUCs for the six hCG analytes and parameters (Table 2). The ROC curves of all 
Table 1 Mean multiple of the median (mMoMs)* for six hCG analytes and parameters compared in subsets of moles vs normal pregnancy, complete vs partial moles and in moles without vs with persistent trophoblastic disease (PTD) (first column represents number of controls in $\mathrm{A}, \mathrm{B}$ and $\mathrm{C}$ and number of patients in $\mathrm{D}$ and $\mathrm{E}$ ).

\begin{tabular}{|c|c|c|c|c|c|c|c|}
\hline Parameter & Controls/Patients $(n)$ & mMoM & S.E. & Patients $(n)$ & mMoM & S.E. & $P$ value \\
\hline \multicolumn{8}{|c|}{ A Normal pregnancies vs all molar pregnancies } \\
\hline $\mathrm{hCG} \alpha$ & 27 & 0.999 & 0.343 & 136 & 0.804 & 0.765 & NS \\
\hline $\mathrm{hCG} \beta$ & 27 & 1.016 & 0.417 & 135 & 6.466 & 4.030 & $<0.001$ \\
\hline $\mathrm{hCG}+\mathrm{hCG} \beta$ & 27 & 1.001 & 0.137 & 204 & 2.430 & 1.265 & $<0.001$ \\
\hline $\mathrm{hCG} \alpha / \mathrm{hCG}+\mathrm{hCG} \beta$ & 27 & 0.997 & 0.254 & 136 & 0.449 & 0.295 & $<0.001$ \\
\hline $\mathrm{hCG} \beta / \mathrm{hCG}+\mathrm{hCG} \beta$ & 27 & 1.009 & 0.323 & 135 & 2.883 & 1.624 & $<0.001$ \\
\hline $\mathrm{hCG} \alpha / \mathrm{hCG} \beta$ & 27 & 0.997 & 0.131 & 132 & 0.524 & 0.168 & $<0.001$ \\
\hline \multicolumn{8}{|c|}{ B Normal pregnancies vs complete molar pregnancies } \\
\hline $\mathrm{hCG} \alpha$ & 27 & 0.999 & 0.343 & 108 & 0.833 & 0.667 & NS \\
\hline $\mathrm{hCG} \beta$ & 27 & 1.016 & 0.417 & 109 & 7.145 & 4.010 & $<0.001$ \\
\hline $\mathrm{hCG}+\mathrm{hCG} \beta$ & 27 & 1.001 & 0.137 & 165 & 2.586 & 1.205 & $<0.001$ \\
\hline $\mathrm{hCG} \alpha / \mathrm{hCG}+\mathrm{hCG} \beta$ & 27 & 0.997 & 0.254 & 108 & 0.414 & 0.264 & $<0.001$ \\
\hline $\mathrm{hCG} \beta / \mathrm{hCG}+\mathrm{hCG} \beta$ & 27 & 1.009 & 0.323 & 109 & 2.991 & 1.745 & $<0.001$ \\
\hline $\mathrm{hCG} \alpha / \mathrm{hCG} \beta$ & 27 & 0.993 & 0.131 & 106 & 0.498 & 0.156 & $<0.001$ \\
\hline \multicolumn{8}{|c|}{ C Normal pregnancies vs partial molar pregnancies } \\
\hline $\mathrm{hCG} \alpha$ & 27 & 0.999 & 0.343 & 28 & 0.689 & 1.071 & NS \\
\hline $\mathrm{hCG} \beta$ & 27 & 1.016 & 0.417 & 26 & 3.618 & 2.670 & $<0.001$ \\
\hline $\mathrm{hCG}+\mathrm{hCG} \beta$ & 27 & 1.001 & 0.137 & 39 & 1.769 & 1.315 & NS \\
\hline $\mathrm{hCG} \alpha / \mathrm{hCG}+\mathrm{hCG} \beta$ & 27 & 0.997 & 0.254 & 28 & 0.583 & 0.368 & $<0.001$ \\
\hline $\mathrm{hCG} \beta / \mathrm{hCG}+\mathrm{hCG} \beta$ & 27 & 1.009 & 0.323 & 26 & 2.431 & 0.848 & $<0.001$ \\
\hline $\mathrm{hCG} \alpha / \mathrm{hCG} \beta$ & 27 & 0.993 & 0.131 & 26 & 0.632 & 0.174 & $<0.001$ \\
\hline \multicolumn{8}{|c|}{ D Complete mole pregnancies vs partial molar pregnancies } \\
\hline $\mathrm{hCG} \alpha$ & 108 & 0.833 & 0.667 & 28 & 0.689 & 1.071 & NS \\
\hline $\mathrm{hCG} \beta$ & 109 & 7.145 & 4.010 & 26 & 3.618 & 2.670 & $<0.001$ \\
\hline $\mathrm{hCG}+\mathrm{hCG} \beta$ & 165 & 2.586 & 1.205 & 39 & 1.769 & 1.315 & $<0.001$ \\
\hline $\mathrm{hCG} \alpha / \mathrm{hCG}+\mathrm{hCG} \beta$ & 108 & 0.414 & 0.268 & 28 & 0.583 & 0.368 & 0.036 \\
\hline $\mathrm{hCG} \beta / \mathrm{hCG}+\mathrm{hCG} \beta$ & 109 & 2.991 & 1.745 & 26 & 2.431 & 0.848 & NS \\
\hline $\mathrm{hCG} \alpha / \mathrm{hCG} \beta$ & 106 & 0.498 & 0.156 & 26 & 0.632 & 0.174 & $<0.001$ \\
\hline \multicolumn{8}{|c|}{ E Complete and partial moles without PTD vs complete and partial moles with PTD } \\
\hline $\mathrm{hCG} \alpha$ & 101 & 0.717 & 0.817 & 35 & 1.052 & 0.526 & 0.003 \\
\hline hCG $\beta$ & 100 & 5.807 & 3.873 & 35 & 8.349 & 3.924 & 0.001 \\
\hline $\mathrm{hCG}+\mathrm{hCG} \beta$ & 161 & 2.284 & 1.277 & 43 & 2.977 & 1.067 & $<0.001$ \\
\hline $\mathrm{hCG} \alpha / \mathrm{hCG}+\mathrm{hCG} \beta$ & 101 & 0.467 & 0.311 & 35 & 0.395 & 0.238 & NS \\
\hline $\mathrm{hCG} \beta / \mathrm{hCG}+\mathrm{hCG} \beta$ & 100 & 2.917 & 1.819 & 35 & 2.787 & 0.866 & NS \\
\hline hCG $\alpha / h C G \beta$ & 99 & 0.534 & 0.168 & 33 & 0.493 & 0.164 & NS \\
\hline
\end{tabular}

${ }^{*} \mathrm{mMoM}$ and S.E. represent the natural logarithmic values of $\mathrm{mMoM}$ and S.E.in the case of $\mathrm{hCG} \alpha$ and $\mathrm{hCG} \alpha \mathrm{hCG} \beta$, while with all other analytes and parameters $\mathrm{mMoM}$ and S.E. apply to square root $\mathrm{mMOM}$ and S.E. values. NS, not significant.

molar pregnancies (Fig. 2A) vs normal pregnancy show AUCs ranging between 0.856 and 0.987 for all $\mathrm{hCG}$ analytes and parameters except for $\mathrm{hCG} \alpha$ whose AUC was 0.618 . hCG $\alpha / \mathrm{hCG} \beta$, hCG $\beta / \mathrm{hCG}+\mathrm{hCG} \beta$ and hCG $\beta$ showed sensitivities of, respectively, $79 \%$, $93 \%$, and $95 \%$, all at $100 \%$ specificity. We also found that $\mathrm{hCG}+\mathrm{hCG} \beta$ and $\mathrm{hCG} \alpha / \mathrm{hCG}+\mathrm{hCG} \beta$ displayed sensitivities of $82 \%$ and $85 \%$ at $90 \%$ specificity.

In the case of hCG + hCG $\beta$ and hCG $\alpha / \mathrm{hCG}+\mathrm{hCG} \beta$ the subset of complete moles (Table 2B, Fig. 2B) revealed higher AUCs (0.911 and 0.932) and the subset of partial moles revealed lower AUCs (0.621 and 0.788) (Table 2C, Fig. 2C) as compared with all molar pregnancies vs normal pregnancy (AUCs of 0.856 and 0.902) (Table 2A, Fig. 2A). Both in complete and partial hydatidiform mole, hCG $\beta$, hCG $\beta / \mathrm{hCG}+$ hCG $\beta$ and $h C G \alpha / h C G \beta$ were excellent diagnostic tests with AUCs ranging between 0.922 and 0.999 to distinguish these subsets from normal pregnancy (Table 2B,C, Fig. 2B,C). In the comparison of complete vs par- tial moles, five out of six hCG analytes and parameters tested (i.e. hCG $\beta$, hCG + hCG $\beta$, hCG $\alpha / \mathrm{hCG}+\mathrm{hCG} \beta$, $\mathrm{hCG} \beta / \mathrm{hCG}+\mathrm{hCG} \beta$ and $\mathrm{hCG} \alpha / \mathrm{hCG} \beta$ ) showed AUCs ranging between 0.602 and 0.797 , while $\mathrm{hCG} \alpha$ showed an AUC of 0.549 (Table 2D, Fig. 2D). In the comparison of moles without or with PTD, hCG $\alpha$, $\mathrm{hCG} \beta, \mathrm{hCG}+\mathrm{hCG} \beta$ and $\mathrm{hCG} \alpha / \mathrm{hCG} \beta$ showed AUCs ranging between 0.591 and 0.698 , whereas the other two parameters revealed even lower AUCs (hCG $\beta /$ hCG + hCG $8: 0.520$, and hCG $\alpha /$ hCG + hCG $\beta$ : 0.568) (Table 2E, Fig. 2E).

\section{Discussion}

The aim of our retrospective study was to explore the significance of six hCG analytes and parameters to distinguish hydatidiform mole from normal pregnancy, to distinguish complete from partial mole, and to assess whether any of these analytes and parameters is able 
A. Normal vs Mole pregnancy

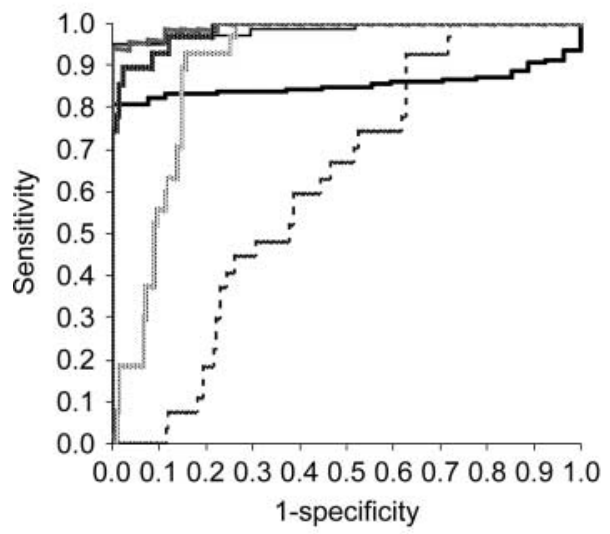

C. Normal vs Partial mole pregnancy

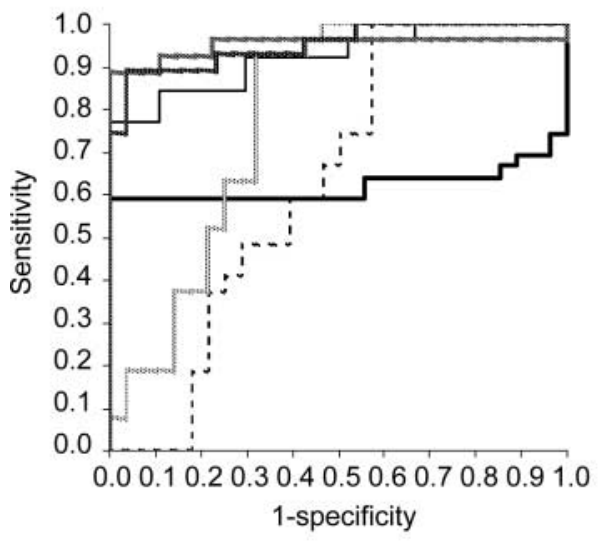

E. Moles without vs With PTD

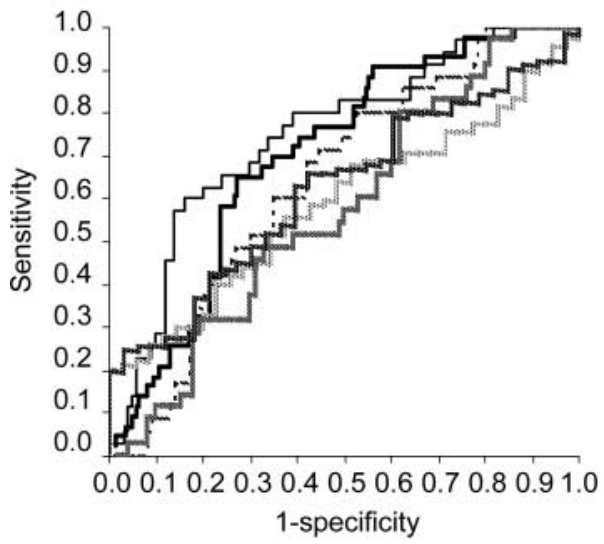

to predict PTD. Specificity and sensitivity of all six hCG analytes and parameters in the various subsets of patient groups were explored in ROC curve analysis and the various AUCs thereof were compared for diagnostic accuracy. To distinguish hydatidiform molar from normal pregnancy, hCG $\beta$, hCG $\beta /$ hCG + hCG $\beta$ and $\mathrm{hCG} \alpha / \mathrm{hCG} \beta$ proved to be excellent diagnostic

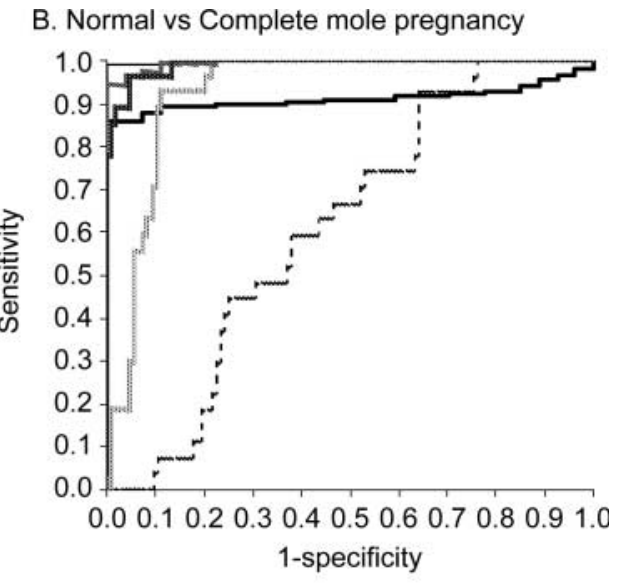

D. Complete vs Partial mole pregnancy
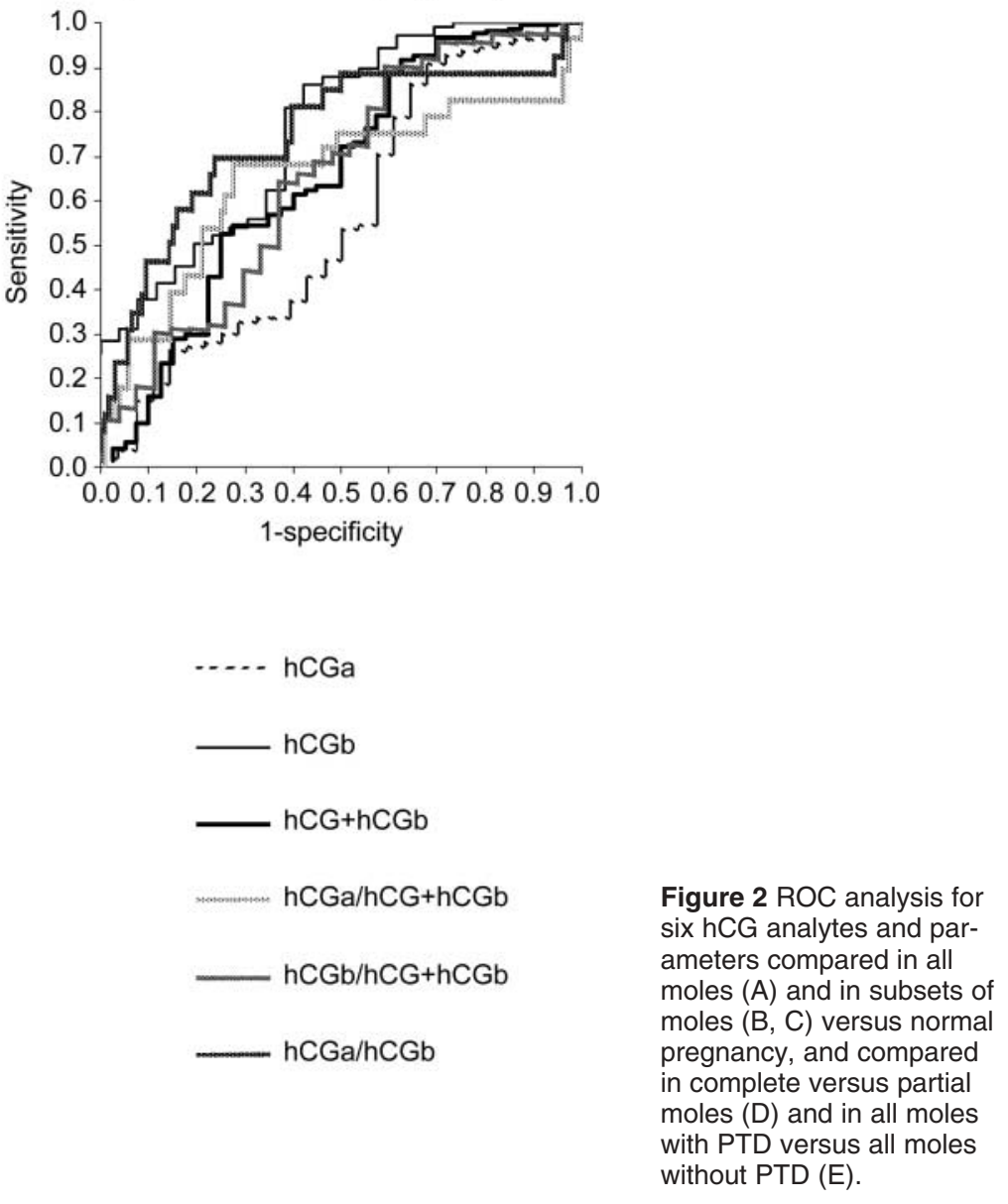

tests with AUCs $>0.9$ in the all moles group as well as in its mole subsets. The comparison of the group of all moles vs normal pregnancy showed AUCs of 0.856 with hCG + hCG $\beta$ and 0.902 for the ratio $\mathrm{hCG} \alpha / \mathrm{hCG}+\mathrm{hCG} \beta$. The diagnostic accuracy of free hCG $\alpha$ was less with AUCs of 0.6 in the case of all the comparisons of moles with normal pregnancy. 
Table 2 Area under the curve (AUC) for six hCG analytes and parameters compared in subsets of moles vs normal pregnancy, in subsets of complete vs partial moles, and in moles without vs with persistent trophoblastic disease (PTD) (first column represents number of controls in $A, B$ and $C$, number of patients with complete moles in D and number of patients without PTD in E; second column represents number of patients in A, B and C, number of patients with partial moles in D and number of patients with PTD in E).

\begin{tabular}{|c|c|c|c|c|}
\hline Parameter & Controls/Complete/No PTD (n) & Patients/Partial/PTD $(n)$ & AUC & 95\% Confidence Interval \\
\hline \multicolumn{5}{|c|}{ A Normal pregnancy vs all moles } \\
\hline $\mathrm{hCG} \alpha$ & 27 & 136 & $0.618^{*}$ & $0.524-0.713$ \\
\hline $\mathrm{hCG} \beta$ & 27 & 135 & 0.984 & $0.968-0.999$ \\
\hline $\mathrm{hCG}+\mathrm{hCG} \beta$ & 27 & 204 & 0.856 & $0.809-0.902$ \\
\hline $\mathrm{hCG} \alpha / \mathrm{hCG}+\mathrm{hCG} \beta$ & 27 & 136 & $0.902^{*}$ & $0.856-0.948$ \\
\hline $\mathrm{hCG} \beta / \mathrm{hCG}+\mathrm{hCG} \beta$ & 27 & 135 & 0.985 & $0.968-1.00$ \\
\hline $\mathrm{hCG} \alpha / \mathrm{hCG} \beta$ & 27 & 132 & $0.987^{*}$ & $0.973-1.00$ \\
\hline \multicolumn{5}{|c|}{ B Normal pregnancies vs complete moles } \\
\hline $\mathrm{hCG} \alpha$ & 27 & 108 & $0.614^{*}$ & $0.513-0.715$ \\
\hline $\mathrm{hCG} \beta$ & 27 & 109 & 0.999 & $0.996-1.00$ \\
\hline$h C G+h C G \beta$ & 27 & 165 & 0.911 & $0.870-0.952$ \\
\hline $\mathrm{hCG} \alpha / \mathrm{hCG}+\mathrm{hCG} \beta$ & 27 & 108 & $0.932^{*}$ & $0.890-0.973$ \\
\hline $\mathrm{hCG} \beta / \mathrm{hCG}+\mathrm{hCG} \beta$ & 27 & 109 & 0.994 & $0.985-1.00$ \\
\hline $\mathrm{hCG} \alpha / \mathrm{hCG} \beta$ & 27 & 106 & $0.994^{*}$ & $0.985-1.00$ \\
\hline \multicolumn{5}{|c|}{ C Normal pregnancies vs partial moles } \\
\hline $\mathrm{hCG} \alpha$ & 27 & 28 & $0.634^{*}$ & $0.481-0.788$ \\
\hline $\mathrm{hCG} \beta$ & 27 & 26 & 0.922 & $0.848-0.995$ \\
\hline $\mathrm{hCG}+\mathrm{hCG} \beta$ & 27 & 39 & 0.621 & $0.474-0.768$ \\
\hline $\mathrm{hCG} \alpha / \mathrm{hCG}+\mathrm{hCG} \beta$ & 27 & 28 & $0.788^{*}$ & $0.662-0.914$ \\
\hline $\mathrm{hCG} \beta / \mathrm{hCG}+\mathrm{hCG} \beta$ & 27 & 26 & 0.947 & $0.871-1.00$ \\
\hline $\mathrm{hCG} \alpha / \mathrm{hCG} \beta$ & 27 & 26 & $0.962^{*}$ & $0.917-1.00$ \\
\hline \multicolumn{5}{|c|}{ D Complete vs partial moles } \\
\hline $\mathrm{hCG} \alpha$ & 108 & 28 & $0.549 *$ & $0.413-0.686$ \\
\hline $\mathrm{hCG} \beta$ & 109 & 26 & $0.797^{*}$ & $0.703-0.891$ \\
\hline $\mathrm{hCG}+\mathrm{hCG} \beta$ & 165 & 39 & $0.719 *$ & $0.621-0.816$ \\
\hline $\mathrm{hCG} \alpha / \mathrm{hCG}+\mathrm{hCG} \beta$ & 108 & 28 & 0.629 & $0.504-0.754$ \\
\hline $\mathrm{hCG} \beta / \mathrm{hCG}+\mathrm{hCG} \beta$ & 109 & 26 & $0.602^{*}$ & $0.477-0.726$ \\
\hline hCG $\alpha / \mathrm{hCG} \beta$ & 106 & 26 & 0.730 & $0.610-0.850$ \\
\hline \multicolumn{5}{|c|}{ E All moles without vs with PTD } \\
\hline $\mathrm{hCG} \alpha$ & 101 & 35 & 0.666 & $0.569-0.764$ \\
\hline $\mathrm{hCG} \beta$ & 100 & 35 & 0.698 & $0.595-0.801$ \\
\hline $\mathrm{hCG}+\mathrm{hCG} \beta$ & 161 & 43 & 0.688 & $0.605-0.772$ \\
\hline $\mathrm{hCG} \alpha / \mathrm{hCG}+\mathrm{hCG} \beta$ & 101 & 35 & $0.568^{*}$ & $0.461-0.675$ \\
\hline $\mathrm{hCG} \beta / \mathrm{hCG}+\mathrm{hCG} \beta$ & 100 & 35 & 0.520 & $0.411-0.630$ \\
\hline $\mathrm{hCG} \alpha / \mathrm{hCG} \beta$ & 99 & 33 & $0.591^{*}$ & $0.478-0.704$ \\
\hline
\end{tabular}

${ }^{*}$ Reversal of study and control groups reveals AUC $>0.5$.

To distinguish complete from partial moles, five out of the six analytes and parameters tested (i.e. hCG $\beta$, $\mathrm{hCG}+\mathrm{hCG} \beta$, hCG $\alpha / \mathrm{hCG}+\mathrm{hCG} \beta$, hCG $\beta / \mathrm{hCG}+\mathrm{hCG}$ and $\mathrm{hCG} \alpha / \mathrm{hCG} \beta$ ) were found to have AUCs in the range of 0.6 to 0.8 , whereas $\mathrm{hCG} \alpha$ showed an even lower AUC of 0.549. To predict PTD after evacuation of a hydatidiform mole, we found $\mathrm{hCG} \alpha, \mathrm{hCG} \beta, \mathrm{hCG}+$ $\mathrm{hCG} \beta$ and $\mathrm{hCG} \alpha / \mathrm{hCG} \beta$ having AUCs in the range of 0.6 to 0.7 . The other two parameters proved to have even lower AUCs (between 0.5 and 0.6). Our finding that the values of hCG $\beta$, hCG + hCG $\beta$, and the ratio of $\mathrm{hCG} \beta / \mathrm{hCG}+\mathrm{hCG} \beta$ in blood withdrawn prior to evacuation are significantly higher, and the ratios of $\mathrm{hCG} \alpha / \mathrm{hCG}+\mathrm{hCG} \beta$ and $\mathrm{hCG} \alpha / \mathrm{hCG} \beta$ are significantly lower in patients with hydatidiform mole as compared with normal pregnancy is in accordance with an earlier report which included only 5 patients with a hydatidiform mole (15). Other studies with limited numbers of patients with hydatidiform mole, also showed that hCG $\beta$ concentration (17) and the ratio hCG $\beta /$ hCG +
hCG $\beta(17,19)$ were significantly higher while hCG $\alpha$ concentrations were not different in hydatidiform mole (17). Berkowitz et al. (14) reported significantly higher concentrations of hCG $\alpha$, hCG $\beta$, percentage hCG $\alpha$ and percentage hCG $\beta$ (i.e. the free subunit to total subunit ratios), and no effect on the $\mathrm{hCG} \beta / \mathrm{hCG} \alpha$ ratio in partial moles $(n=8)$ compared with normal pregnancy. Our data on hCG $\alpha / \mathrm{hCG}+\mathrm{hCG} \beta$ and hCG $\alpha / \mathrm{hCG} \beta$ ratios are not in line with that study as we found a significant decrease in these levels. Interestingly, in the case of the complete mole subgroup comprising more patients $(n=20)$, the same authors reported significantly lower levels of the hCG $\alpha$ to intact hCG ratio and significantly higher concentrations of the $\mathrm{hCG} \beta / \mathrm{hCG} \alpha$ which is in line with our data. It has to be noted that Berkowitz et al. (14) used intact hCG to calculate the ratios of free $\alpha$ and free $\beta$ to hCG, whereas we measured total hCG immunoreactivity, which included intact hCG as well as free hCG $\beta$-subunit. Evidently, the marked increased free 
hCG $\beta$ concentrations in molar pregnancy will affect this ratio for which no correction could be made in the hCG + hCG $\beta$ assay because of the very different affinities of the polyclonal antiserum towards the free hCG $\beta$-subunit and the hCG $\beta$ as a part of the holohCG molecule. Very specific assays for all forms of hCG $\beta$ have been described (28). The use of a specific, more generally used, holo-hCG assay would have yielded different ratios. Nevertheless, we have used a $\mathrm{hCG}+\mathrm{hCG} \beta$ assay because it is superior in the diagnosis of trophoblastic tumors. To our knowledge the present study is the first to evaluate the diagnostic accuracy of the $6 \mathrm{hCG}$ analytes and parameters in a substantial number of samples, showing that hCG $\beta$, hCG $\beta / \mathrm{hCG}+\mathrm{hCG} \beta$ and hCG $\alpha / \mathrm{hCG} \beta$ are excellent diagnostic tests as indicated by AUCs above 0.9 to distinguish partial and complete hydatidiform molar from normal pregnancy. The sensitivities of these three diagnostic tests to distinguish hydatidiform molar pregnancy from normal pregnancy were, respectively, 95\%, 93\% and 79\%, all at 100\% specificity, while we found sensitivities of $82 \%$ and $85 \%$ at $90 \%$ specificity with $\mathrm{hCG}+\mathrm{hCG} \beta$ and $\mathrm{hCG} \alpha / \mathrm{hCG}+$ hCG $\beta$.

We found significantly lower mMoMs of hCG $\beta$ and hCG + hCG $\beta$ and significantly higher hCG $\alpha /$ hCG + hCG $\beta$ and hCG $\alpha /$ hCG $\beta$ ratios in partial moles as compared with complete moles. hCG $\alpha$ and hCG $\beta / \mathrm{hCG}+$ hCG $\beta$ were not different in this comparison. Irrespective of the presence or absence of statistical significance, none of these six analytes or parameters proved to have meaningful AUCs (range: 0.549-0.797). In a smaller study comprising 20 complete moles and 8 partial moles, Berkowitz et al. (14) reported similar results for hCG $\alpha$, hCG $\beta$ and hCG $\alpha /$ hCG $\beta$. These investigators found no significant difference in intact hCG concentrations when distinguishing partial from complete moles. Why hCG $\beta$ is synthesized more abundantly in complete hydatidiform mole than in partial moles or in normal pregnancy is unknown. hCG is synthesized in cytotrophoblasts and more abundantly in syncytiotrophoblasts $(29,30)$. Messenger-RNA for $\mathrm{hCG} \alpha$ is encoded by a single gene on chromosome 6 (31), whereas the $\beta$-subunit of hCG is encoded by four genes - hCG $\beta-3,-5,-7$, and -8 - located on chromosome $19 q 13.3(31,32)$. hCG $\alpha$ - and $\beta$-subunits are thus synthesized separately, and their production is regulated independently during pregnancy and in trophoblastic disease $(33,34)$. Berkowitz et al. (14) suggested that the percentage free hCG $\beta$ level might reflect the level of differentiation and hyperplasia of the trophoblast, since the level of free hCG $\beta$ increases up to $0.5 \%$ at five weeks of normal gestation, to $1 \%$ in partial hydatidiform mole, to $2.4 \%$ in complete hydatidiform mole, and as high as $9.2 \%$ in choriocarcinoma. Indeed, Hay (16) proposed a regulatory mechanism to link irregularities in trophoblastic differentiation to altered biosynthesis of hCG. In proliferating syncytium formed by differentiating cytotrophoblasts, amplification of hCG genes results in excess mRNA for hCG $\beta$ subunits. All free hCG $\alpha$ will be used to produce hCG and the remaining hCG $\beta$ will be released together with intact hCG. In the same way, it is feasible to think that in partial mole, which contains both normal trophoblast and hyperplastic trophoblast, less free hCG $\beta$ is synthesized as compared with complete moles.

Identifying patients with increased risk for developing PTD after evacuation of hydatidiform mole is of great interest. Approximately $20 \%$ of patients with a complete hydatidiform mole will suffer from PTD that requires chemotherapy treatment. Prophylactic chemotherapy reduces the incidence of PTD to $4-12 \%(10,11)$. Optimism about prophylactic chemotherapy is tempered by a prospective randomized controlled trial by Kim et al. (35) who found that prophylactic chemotherapy indeed reduced the incidence of PTD in high risk patients (from $31 \%$ to $10 \%$ ), but these patients needed more courses of chemotherapy (mean $2.5 \pm 0.5$ (S.E.) vs $1.4 \pm 0.5$ courses, $P<0.005$ ), suggesting that prophylactic therapy increases tumor resistance and morbidity by selection and proliferation of cells that are resistant to the effect of chemotherapy. To prevent unnecessary treatment as well as resistance to chemotherapy, it is challenging to find an adequate diagnostic modality that identifies patients at increased risk for developing PTD. We found that serum concentrations of $\mathrm{hCG} \alpha$, hCG $\beta$, and hCG + hCG $\beta$ were significantly higher in patients with PTD as compared with those in which spontaneous regression after evacuation occurred. These hCG analytes showed only moderate diagnostic accuracy (with AUCs in the range of 0.6 to 0.7 ) indicating a limited clinical relevance of the observed differences in hCG concentrations between these groups. None of the calculated ratios were significantly different and consequently all had a poor diagnostic accuracy to predict PTD. In contrast to our data, a number of studies, all with limited patient samples, reported that the hCG $\beta /$ total hCG ratio is a predictor of PTD $(18-20)$. These studies included patients with unspecified hydatidiform $(18,19)$ or complete (20) hydatidiform moles. Berkowitz et al. (14) reported that none of the evaluated hCG parameters, equal to those in our study, were associated with the development of PTD. Our study showed that $\mathrm{hCG} \alpha$, hCG $\beta$, hCG + hCG $\beta$ and the ratio hCG $\alpha / \mathrm{hCG} \beta$ with AUCs in the range of 0.6 to 0.7 are of less value in the prediction of PTD, and it is unlikely that a clinician will start prophylactic chemotherapy on the basis of the results obtained with these tests. Therefore, new modalities should be explored to find a reliable predictor for PTD. Amongst these is the serum concentration of the hCG $\beta$-core fragment which was found to be rising prior to intact hCG in patients with hydatidiform mole who developed PTD as compared with patients with hydatidiform mole with remission of hCG after mole evacuation (hydatidiform mole, $n=14$ of which 4 patients had 
PTD) (36). Another potentially interesting parameter is hyperglycosylated hCG which was found to rise from $25 \%$ to $80 \%$ of total serum hCG when patients with persistent low levels of hCG developed gestational trophoblastic neoplasm (37). The clinical value of this test in predicting PTD after hydatidiform mole remains to be elucidated.

In summary, our study based on a large patient sample showed that hCG $\beta$ in serum, and the ratios of hCG $\beta / \mathrm{hCG}+\mathrm{hCG} \beta$ and hCG $\alpha / \mathrm{hCG} \beta$ are excellent diagnostic tests and parameters to make the distinction biochemically between hydatidiform mole and normal pregnancy at the $100 \%$ specificity level with more than $90 \%$ sensitivity. For practical use, the hCG $\beta$ assay is recommended. The distinction between complete and partial hydatidiform mole cannot reliably be made with any of the tested analytes or parameters because diagnostic accuracy of these tests is at best qualified as moderately applicable. Finally, we found that although hCG $\alpha$, hCG $\beta$ and hCG + hCG $\beta$ concentrations are significantly elevated in the case of PTD, none of the six investigated hCG parameters had adequate diagnostic accuracy to permit the clinician to advise patients to undertake prophylactic chemotherapy after evacuation of a hydatidiform mole.

\section{Acknowledgements}

The authors acknowledge Henk JW Ariaens, RUNMC Department of Chemical Endocrinology, for expert technical assistance, Drs G Peter Vooijs and Christine A Hulsbergen-van de Kaa, RUNMC Department of Pathology, for the review of the histology, and Wim H Doesburg and Wim AJG Lemmens, RUNMC Department of Medical Informatics, Epidemiology and Statistics, for statistical advice and their support in processing the data.

\section{References}

1 Hussa RO. The Clinical Marker hCG. New York: Praeger Publishers, 1987.

2 Bentley RC. Pathology of gestational trophoblastic disease. Clinical Obstetrics and Gynecology 200346 513-522.

3 Matsuda T \& Wake N. Genetics and molecular markers in gestational trophoblastic disease with special reference to their clinical application. Best Practice and Research Clinical Obstetrics and Gynaecology $200317827-836$.

4 Steigrad SJ. Epidemiology of gestational trophoblastic diseases. Best Practice and Research Clinical Obstetrics and Gynaecology $200317837-847$.

5 Berkowitz RS \& Goldstein DP. Gestational trophoblastic disease. Cancer 199576 2079-2085.

6 Bagshawe KD, Lawler SD, Paradinas FJ, Dent J, Brown P \& Boxer GM. Gestational trophoblastic tumours following initial diagnosis of partial hydatidiform mole. Lancet 1990335 1074-1076.

7 Berkowitz RS, Goldstein DP \& Bernstein MR. Natural history of partial molar pregnancy. Obstetrics and Gynecology $1985 \mathbf{6 6}$ $677-681$.
8 Goto S, Yamada A, Ishizuka T \& Tomoda Y. Development of postmolar trophoblastic disease after partial molar pregnancy. Gynecologic Oncology 199348 165-170.

9 Rice LW, Berkowitz RS, Lage JM, Goldstein DP \& Bernstein MR. Persistent gestational trophoblastic tumor after partial hydatidiform mole. Gynecologic Oncology 199036 358-362.

10 Goldstein DP, Berkowitz RS \& Bernstein MR. Management of molar pregnancy. Journal of Reproductive Medicine 198126 $208-212$.

11 Curry SL, Hammond CB, Tyrey L, Creasman WT \& Parker RT. Hydatidiform mole: diagnosis, management, and long-term follow up of 347 patients. Obstetrics and Gynecology $1975451-8$.

12 Thomas CM, Reijnders FJ, Segers MF, Doesburg WH \& Rolland R. Human choriogonadotropin (hCG): comparisons between determinations of intact hCG, free hCG beta-subunit, and 'total' hCG + beta in serum during the first half of high-risk pregnancy. Clinical Chemistry 199036 651-655.

13 Elegbe RA, Pattillo RA, Hussa RO, Hoffmann RG, Damole IO \& Finlayson WE. Alpha subunit and human chorionic gonadotropin in normal pregnancy and gestational trophoblastic disease. Obstetrics and Gynecology $198463335-337$.

14 Berkowitz RS, Ozturk M, Goldstein DP, Bernstein MR, Hill L \& Wands JR. Human chorionic gonadotropin and free subunits' serum levels in patients with partial and complete hydatidiform moles. Obstetrics and Gynecology $1989 \mathbf{7 4} 212-216$.

15 Gaspard UJ, Reuter AM, Deville J-L, Vrindts-Gevaert Y, Bagshawe KD \& Franchimont P. Serum concentration of human chorionic gonadotropin and its alpha and beta subunits. 2. Trophoblastic tumours. Clinical Endocrinology 198013 319-329.

16 Hay DL. Histological origins of discordant chorionic gonadotropin secretion in malignancy. Journal of Clinical Endocrinology and Metabolism 198866 557-564.

17 Ozturk M, Berkowitz R, Goldstein D, Bellet D \& Wands JR. Differential production of human chorionic gonadotropin and free subunits in gestational trophoblastic disease. American Journal of Obstetrics and Gynecology 1988158 193-198.

18 Khazaeli MB, Hedayat MM, Hatch KD, To AC, Soong SJ, Shingleton HM, Boots LR \& LoBuglio AF. Radioimmunoassay of free beta-subunit of human chorionic gonadotropin as a prognostic test for persistent trophoblastic disease in molar pregnancy. American Journal of Obstetrics and Gynecology $1986 \quad 155$ $320-324$.

19 Khazaeli MB, Buchina ES, Pattillo RA, Soong SJ \& Hatch KD. Radioimmunoassay of free beta-subunit of human chorionic gonadotropin in diagnosis of high-risk and low-risk gestational trophoblastic disease. American Journal of Obstetrics and Gynecology $1989160444-449$.

20 Mungan T, Kuscu E, Ugur M, Dabakoglu T, Senses E \& Cobanoglu O. Screening of persistent trophoblastic disease with various serum markers. European Journal of Gynaecological Oncology $199819495-497$.

21 Yedema KA, Verheijen RH, Kenemans P, Schijf CP, Borm GF, Segers MF \& Thomas CM. Identification of patients with persistent trophoblastic disease by means of a normal human chorionic gonadotropin regression curve. American Journal of Obstetrics and Gynecology $1993 \mathbf{1 6 8} 787-792$.

22 Thomas CM, Segers MF \& Houx PC. Comparison of the analytical characteristics and clinical usefulness in tumour monitoring of fifteen hCG(- beta) immunoassay kits. Annals of Clinical Biochemistry 198522 236-246.

23 Khazaeli MB, England BG, Dieterle RC, Nordblom GD, Kabza GA \& Beierwaltes WH. Development and characterization of a monoclonal antibody which distinguishes the beta subunit of human chorionic gonadotropin (beta hCG) in the presence of the hCG. Endocrinology 1981109 1290-1292.

24 Thomas CM \& Segers MF. Quantification of choriogonadotropin: differential cross-reactivities of the free hCG beta-subunit with eight different monoclonal antibody-based hCG and (hCG + beta) 'sandwich'-type assays. Clinical Chemistry $1989 \quad 35$ 1791-1792. 
25 Kletzky OA, Nakamura RM, Thorneycroft IH \& Mishell DR Jr. Log normal distribution of gonadotropins and ovarian steroid values in the normal menstrual cycle. American Journal of Obstetrics and Gynecology $1975 \mathbf{1 2 1} 688-694$.

26 Zweig MH, Broste SK \& Reinhart RA. ROC curve analysis: an example showing the relationships among serum lipid and apolipoprotein concentrations in identifying patients with coronary artery disease. Clinical Chemistry 199238 1425-1428.

27 Zweig MH \& Campbell G. Receiver-operating characteristic (ROC) plots: a fundamental evaluation tool in clinical medicine. Clinical Chemistry $199339561-577$.

28 Alfthan H, Haglund C, Dabek J \& Stenman UH. Concentrations of human choriogonadotropin, its beta-subunit, and the core fragment of the beta-subunit in serum and urine of men and nonpregnant women. Clinical Chemistry 199238 1981-1987.

29 Shi QJ, Lei ZM, Rao CV \& Lin J. Novel role of human chorionic gonadotropin in differentiation of human cytotrophoblasts. Endocrinology $19931321387-1395$.

30 Hoshina M, Boothby M \& Boime I. Cytological localization of chorionic gonadotropin alpha and placental lactogen mRNAs during development of the human placenta. Journal of Cell Biology 198293 190-198.

31 Naylor SL, Chin WW, Goodman HM, Lalley PA, Grzeschik KH \& Sakaguchi AY. Chromosome assignment of genes encoding the alpha and beta subunits of glycoprotein hormones in man and mouse. Somatic Cell Genetics $19839757-770$.
32 Policastro PF, Daniels-McQueen S, Carle G \& Boime I. A map of the hCG beta-LH beta gene cluster. Journal of Biological Chemistry $19862615907-5916$.

33 Hussa RO. Biosynthesis of human chorionic gonadotropin. Endocrine Reviews $19801268-294$.

34 Jameson JL \& Hollenberg AN. Regulation of chorionic gonadotropin gene expression. Endocrine Reviews $199314203-221$.

35 Kim DS, Moon H, Kim KT, Moon YJ \& Hwang YY. Effects of prophylactic chemotherapy for persistent trophoblastic disease in patients with complete hydatidiform mole. Obstetrics and Gynecology $1986 \mathbf{6 7} 690-694$.

36 Okamoto T, Matsuo K, Niu R, Osawa M \& Suzuki H. Human chorionic gonadotropin (hCG) beta-core fragment is produced by degradation of hCG or free hCG beta in gestational trophoblastic tumors: a possible marker for early detection of persistent postmolar gestational trophoblastic disease. Journal of Endocrinology 2001 $171435-443$.

37 Khanlian SA, Smith HO \& Cole LA. Persistent low levels of human chorionic gonadotropin: a premalignant gestational trophoblastic disease. American Journal of Obstetrics and Gynecology $2003 \mathbf{1 8 8}$ $1254-1259$.

Received 16 February 2005

Accepted 8 July 2005 